\title{
A "Believe It or Not" Episode of Medical Conquests by the Indigenous Peoples of South America and the African Descendants Domiciled Mainly in Tobago
}

\author{
J Jainarinesingh
}

\section{INTRODUCTION}

Except for the professional work conducted by a few adventurous anthropologists such as Roth (1970) and Johannes (1963), little is actually known about the great impact that the Warao of north eastern Venezuela and the Guajiro of Zulia State near to Lake Maracaibo, Venezuela, have made on both allopathic and traditional medicine in the modern world.

During my undergraduate years at the University of the West Indies in St Augustine, Trinidad and Tobago, I ventured out to Venezuela in search of 'food' for my 'hungry' Caribbean Studies paper. Years later, during my postgraduate years in the United States of America (USA), I found similar 'food' to whet the appetite of my research paper on the incidence and management of diabetes mellitus among the Guajiro Indians and I discovered that in spite of the geographical and topographical differences in the physical locations of these two ethnic groups, there still exist remarkable similarities in their food intake, lifestyle, traditional beliefs, family ties and customs.

In my sojourns through relatively remote parts of Venezuela and during the course of my social interludes with these great people, I discovered that they were almost totally non-dependent on modern medical personnel and modern medicine within their immediate environment. The Warao, also known as the 'Boat people', survive on the fauna of the tributaries of the vast Orinoco River and the flora of the dense jungle that yield fresh vegetation and other foods that are loaded with a myriad of botanical and nutritional cures.

Keywords: Guajiro, indigenous, medical anthropology, Warao

West Indian Med J 2014; 63 (1): 92

\section{'MAL AIRE'}

My participant-observation techniques among both indigenous groups revealed that they even share the traditional beliefs of their Central American counterparts. For example, they all believe that most diseases are caused by 'mal aire' or 'bad air'. To treat this affliction, they use a lit candle and a glass which most times creates suction. This process is known as 'ventosa' or 'cupping' in English. This practice is not unknown to other cultures. It is also the belief that many health problems arise from hot or cold conditions in the atmosphere and that cold will lead to respiratory problems, headaches, paralysis, stomach cramps and teething pains among others and that hot conditions will lead to constipation, intestinal disorders and

From: Chase Village, Chaguanas, Trinidad and Tobago.

Correspondence: Dr J Jainarinesingh, LP 61, John Elie Road, Chase Village, Chaguanas, Trinidad and Tobago. E-mail: jjsingh2005@yahoo.com problems aligned to reproduction. It is also a shared belief that the incidence of tuberculosis is aligned to their 'cold air' belief. Both hot and cold beliefs are similar to the Hippocratic theory of disease and the fact that the four 'humours' within the body must be in a state of balance for bodily functions to work well. These humours are known as blood, phlegm, yellow bile and black bile. The concept of balance is akin to homeostasis in modern medicine.

\section{'MAL DE OJO'}

Simply stated, 'mal de ojo' means 'bad eye' in English, and although a relatively small group of people may not have heard of its existence in common folklore and even among selective scientific circles, it is quite well known by almost all nationalities. I recently returned from the beautiful island of Tobago and I verbally communicated with many an African Tobagonian and also with others of African descent. I was not at all surprised to learn that 'bad eye' or 'mal jo' - which is the dialect for 'mal de ojo' - is also a household word throughout the island. In fact, I learnt that the parents of children can give the worst type of 'mal jo'.

I recall an elderly man telling a young mother in Plymouth, Tobago, that "like you want to kill dis chile? Look at how much bite mark top de chile skin!" ("It looks like you want to kill this child. Look at how many bite marks are on the child's skin.") The young mother started to cry of guilt and muttered, "But is meh only chile, wha a go do? He fadder nah livin." ("But he is my only child, what should I do? His father is not living.") The 'village priest' prayed for the child while he was breaking a piece of twig that resembled a part of a coconut leaf and subsequently explained to me that 'mal jo' is an almost deadly condition that people can put on their own children, on their friends, relatives, siblings and even on themselves. He went on to explain that some people could give you 'envy mal jo' if you get a promotion in your job and they could cause you to fall very ill and even die. He concluded that the remedies for 'mal jo' is "endless prayers and bush bath".

Prior to this experience, my Nigerian professor who taught me pre-clinical medicine also shared many West African traditions with me while we were consuming bowls of 'suya', 'pepper soup', or sipping 'palm wine'. He intimated to me a belief and tradition that is very similar to 'mal de ojo' except that it is known by a different word in the Ibo language. I am now convinced that 'folk traditions' and beliefs permeate the minds and customary beliefs of almost every culture and that based upon reports, some diseases that are deemed 'incurable' are actually cured by 'Curanderos' or 'village priests' in places such as Nigeria, Brazil, Colombia and also in parts of the Caribbean. 
In addition to the above, the concept of hot and cold foods is still true and alive; for example, they classify cold foods as fresh fruits, grasses and sugarcane and hot foods such as chocolate and coffee. They treat the 'hot' illnesses with a cold remedy or a cold food remedy. Their concept of 'mal de ojo' is based on the belief that a parent's 'over-loving' for an offspring may lead to 'mal de ojo' on the part of the child. The result is incessant crying, high fever and discomfort. Both the 'Curandero' (village priest) and the 'Shaman' would usually use leaves or twigs of a plant to touch the child and in so doing extract the 'evil' or the 'mal de ojo'. This practice is also widely used amongst village priests within the East Indian community of Trinidad and I have actually witnessed instant cures for children who are afflicted with 'bad eye'.

The incidence of diabetes mellitus as is known in the modern community is now seeping into these traditional indigenous communities. Both the Guajiro and the Warao share a lifestyle that is based on hunting, fishing and gathering. They both walk for very long distances on a daily basis, they sail and/or swim to catch their fish and make full use of the fresh air and other flora and fauna of their immediate environment. Known to be excellent tree-climbers, the Warao imitate the climbing skills and agility of animals that abound in the jungle. The Guajiro are known to be excellent sailors and runners and are also known to mimic animals of the environment. Due to the fact that these two indigenous groups are not sedentary, there is a very low incidence of diabetes. The 'clínicas' that are run by the Venezuelan Government in both geographical regions are almost empty from time to time because of the unwillingness on the part of the indigenous Indians to access modern medical care. During my conversation with the government nurses at a clinic in Tucupita, Venezuela, I learnt that the Warao are very unwilling to use modern medicine or to be photographed in or around the clinic.

The approach to members of both indigenous groups toward wound care is both radical and alarming. They mainly use the botanical preparations to treat all sorts of cuts, bruises, stings and snake bites among other skin disruptions. They both use botanical potions to cure themselves from the after effects of poisoning and skin diseases. Their method of treating an open wound is different and 'natural'; rather than using sutures to close the wound, they allow it to heal naturally.

It is hoped that other researchers in medical anthropology will continue to study indigenous peoples and the invaluable contribution that they make to the discipline of complementary medicine.

\section{REFERENCES}

1. Jainarinesingh J. La vida y la cultura material de los Warao [thesis]. St Augustine: The University of the West Indies; 1990.

2. Johannes W. Indios de la región Orinoco Ventuari. Caracas: Fundación la Salle de Ciencias Naturales; 1966.

3. Roth WE. The animism and folklore of the Guiana Indians. Guyana: The Caribbean Press; 1915. 